\title{
Hyperoxemia in postsurgical sepsis/septic shock patients is associated with reduced mortality
}

\author{
Marta Martín-Fernández ${ }^{1,2,3^{*}}$, María Heredia-Rodríguez ${ }^{2,3,4 \dagger}$, Irene González-Jiménez², \\ Mario Lorenzo-Lópezz 2,3,5, Estefanía Gómez-Pesquera ${ }^{2,3,5}$, Rodrigo Poves-Álvarez ${ }^{2,3,5}$, F. Javier Álvarez 2,3,6, \\ Pablo Jorge-Monjas 2,3,5, Juan Beltrán-DeHeredia ${ }^{7}$, Eduardo Gutiérrez-Abejón ${ }^{3,6}$, Francisco Herrera-Gómez ${ }^{3,8}$, \\ Gabriella Guzzo ${ }^{8}$, Esther Gómez-Sánchez ${ }^{2,3,5}$, Álvaro Tamayo-Velasco ${ }^{3,9}$, Rocío Aller ${ }^{1,2,10}$, Paolo Pelosi ${ }^{11,12 \dagger}$, \\ Jesús Villar ${ }^{13,14,15^{*}+}$ (1) and Eduardo Tamayo $2,3,5,7+$
}

\begin{abstract}
Background: Despite growing interest in treatment strategies that limit oxygen exposure in ICU patients, no studies have compared conservative oxygen with standard oxygen in postsurgical patients with sepsis/septic shock, although there are indications that it may improve outcomes. It has been proven that high partial pressure of oxygen in arterial blood $\left(\mathrm{PaO}_{2}\right)$ reduces the rate of surgical-wound infections and mortality in patients under major surgery. The aim of this study is to examine whether $\mathrm{PaO}_{2}$ is associated with risk of death in adult patients with sepsis/septic shock after major surgery.

Methods: We performed a secondary analysis of a prospective observational study in 454 patients who underwent major surgery admitted into a single ICU. Patients were stratified in two groups whether they had hyperoxemia, defined as $\mathrm{PaO}_{2}>100 \mathrm{mmHg}(n=216)$, or $\mathrm{PaO}_{2} \leq 100 \mathrm{mmHg}(n=238)$ at the day of sepsis/septic shock onset according to SEPSIS-3 criteria maintained during 48 h. Primary end-point was 90-day mortality after diagnosis of sepsis. Secondary endpoints were ICU length of stay and time to extubation.

Results: In patients with $\mathrm{PaO}_{2} \leq 100 \mathrm{mmHg}$, we found prolonged mechanical ventilation (2 [8] vs. 1 [4] days, $p<0.001$ ), higher ICU stay (8 [13] vs. 5 [9] days, $p<0.001$ ), higher organ dysfunction as assessed by SOFA score (9 [3] vs. 7 [5], $p<0.001)$, higher prevalence of septic shock (200/238, 84.0\% vs 145/216) $67.1 \%, p<0.001)$, and higher 90 -day mortality (37.0\% [88] vs. 25.5\% [55], $p=0.008$ ). Hyperoxemia was associated with higher probability of 90-day survival in a multivariate analysis (OR 0.61, 95\% Cl: $0.39-0.95, p=0.029)$, independent of age, chronic renal failure, procalcitonin
\end{abstract}

\footnotetext{
*Correspondence: mmartin.iecscyl@saludcastillayleon.es;

jesus.villar54@gmail.com

†Marta Martín-Fernández and María Heredia-Rodríguez have equal

contribution as first authors; Paolo Pelosi, Jesús Villar and Eduardo Tamayo

have equal contribution as senior authors.

${ }^{3}$ Centro de Investigación Biomédica en Red de Enfermedades Infecciosas

(CIBERINFEC), Instituto de Salud Carlos III, Madrid, Spain

${ }^{14}$ Research Unit, Hospital Universitario Dr. Negrín, Barranco de la Ballena

s/n, 4th Floor-South Wing, 35019 Las Palmas de Gran Canaria, Spain

Full list of author information is available at the end of the article
}

(c) The Author(s) 2022. Open Access This article is licensed under a Creative Commons Attribution 4.0 International License, which permits use, sharing, adaptation, distribution and reproduction in any medium or format, as long as you give appropriate credit to the original author(s) and the source, provide a link to the Creative Commons licence, and indicate if changes were made. The images or other third party material in this article are included in the article's Creative Commons licence, unless indicated otherwise in a credit line to the material. If material is not included in the article's Creative Commons licence and your intended use is not permitted by statutory regulation or exceeds the permitted use, you will need to obtain permission directly from the copyright holder. To view a copy of this licence, visit http://creativecommons.org/licenses/by/4.0/. The Creative Commons Public Domain Dedication waiver (http://creativeco mmons.org/publicdomain/zero/1.0/) applies to the data made available in this article, unless otherwise stated in a credit line to the data. 
levels, and APACHE II score > 19. These findings were confirmed when patients with severe hypoxemia at the time of study inclusion were excluded.

Conclusions: Oxygenation with a $\mathrm{PaO}_{2}$ above $100 \mathrm{mmHg}$ was independently associated with lower 90-day mortality, shorter ICU stay and intubation time in critically ill postsurgical sepsis/septic shock patients. Our findings open a new venue for designing clinical trials to evaluate the boundaries of $\mathrm{PaO}_{2}$ in postsurgical patients with severe infections.

Keywords: Hyperoxemia, Outcome, Sepsis, Septic Shock, Surgical patients, Infection

\section{Background}

Sepsis and septic shock are major causes of mortality in surgical patients [1]. It is estimated that up to one-third of total cases of sepsis are among surgical patients [2]. More than 1.7 million people in the United States (US) are diagnosed with sepsis each year [3], which causes 270,000 deaths [4] and accounts for the highest hospital cost [5]. In Spain, sepsis incidence and associated mortality increased from 200 cases and 56 deaths per 100,000 inhabitants in the year 2000 to 480 cases and 830 deaths per 100,000 population in 2013 , respectively [6].

Septic shock patients admitted to the ICU consume many healthcare resources and require early management and treatment [7]. In the pathophysiology of shock, there is an imbalance between oxygen supply and oxygen consumption [8]. Therefore, one of the mainstays of treatment for septic shock is oxygen administration. However, the appropriate regimen of oxygen administration is unknown and the Surviving Sepsis Guidelines do not provide a formal recommendation for oxygen targets [7]. On the other hand, the effects of hyperoxaemia may also be beneficial by enhancing host defense against extracellular pathogens by neutrophils [9]. Neutrophils' bactericidal activity is mediated by oxidative killing, a crucial defense mechanism against surgical pathogens [10]. This potent bactericidal mechanism is dependent on the production of superoxide radicals from molecular oxygen [11].

Several studies have shown that the administration of oxygen for achieving high partial pressure of oxygen in arterial blood $\left(\mathrm{PaO}_{2}\right)$ reduces the rate of surgical-wound infections and mortality in patients under major surgery [11-13]. A recent meta-analysis of 17 randomized controlled trials involving more than 8000 patients concluded that perioperative hyperoxia $\left(\mathrm{FiO}_{2}\right.$ $0.80)$ reduced the risk of surgical site infections in colorectal surgery [14]. Few studies have addressed the assessment of hyperoxaemia in sepsis and their results do not shed light on the problem [14-17]. A post-hoc analysis of the HYPERS2S study found that hyperoxaemia may be associated with increased 90-day mortality [16] and, in contrast, a post-hoc analysis of the
ICU-ROX study found that conservative oxygen therapy increases 90 -day mortality in patients with sepsis [17].

In view of the paucity of clinical evidence, the debate on the optimal oxygen concentration in sepsis/septic shock patients has only just begun. In this study we performed an exploratory post hoc analysis to evaluate the effect on 90-day mortality of conservative versus standard oxygen therapy administered during the first $48 \mathrm{~h}$ after the onset of sepsis/septic shock. This information may help to both guide the performance of a future clinical trial and test the hypothesis that hyperoxemia would improve outcome compared to conservative oxygen therapy in patients with sepsis/septic shock.

\section{Methods \\ Patient population}

This is a secondary analysis of a prospective cohort of 454 adult patients ( $\geq 18$ years old) who underwent major surgery and were admitted to the Surgical ICU of the 700bed Hospital Clínico Universitario, Valladolid, Spain, from December 2006 to February 2017, with a diagnosis of sepsis or septic shock according to SEPSIS-3 definitions and need for invasive mechanical ventilation [18]. Patients meeting clinical criteria for sepsis/septic shock with a negative microbiological culture were excluded. The study protocol was approved by the Ethics Committee for Clinical Research, Hospital Clínico Universitario de Valladolid, Valladolid, Spain (approval No. PI 20-2070). This study followed current Spanish legislation for biomedical research, fulfilling the standards indicated by the Declaration of Helsinki. Written informed consent was obtained from patients, patients' relatives or their legal representative before enrolment.

We stratified patients into two groups according to the value of $\mathrm{PaO}_{2}$ on the day of sepsis or septic shock onset, maintained during $48 \mathrm{~h}$ : (i) hyperoxemia $\left(\mathrm{PaO}_{2}>100 \mathrm{mmHg}\right)$ group, or (ii) normoxemia $\left(\mathrm{PaO}_{2} \leq 100 \mathrm{mmHg}\right)$ group [19].

Patients were managed and treated (Additional file 1: File 1) according to current guidelines for general critical care management [18], which include the following: 
(i) early identification of causative microorganism, optimization of intravenous antibiotic selection and timely administration on the basis of antibiogram; (ii) fluid resuscitation and vasopressor use were individualized with the goal of maintaining a systolic blood pressure $\geq 90 \mathrm{mmHg}$ or a mean arterial pressure $\geq 65 \mathrm{mmHg}$; (iii) to maintain hemoglobin between 7 and $10 \mathrm{~g} / \mathrm{dL}$ according to the patient's overall clinical status [7].

The choice of drugs for sedation and analgesia, hemodynamic management modalities, and the decision to perform tracheostomy were left to the discretion of the attending physician. Weaning from the ventilator was started when the attending physician considered it clinically appropriate. Gastric protection was routinely performed with omeprazole $(20 \mathrm{mg} / \mathrm{iv})$ during the first $24 \mathrm{~h}$ of ICU stay.

\section{Data collection and follow-up}

Patients admitted into the ICU were screened daily during the study period to identify eligible patients and determine the onset of severe sepsis/septic shock. We used a specific standardized form to collect demographic and clinical data, including hematological, biochemical, radiological, microbiological, and biomarker levels in the first $24 \mathrm{~h}$ after diagnosis of sepsis/septic shock. Severity of illness was assessed using the Sequential Organ Failure Assessment (SOFA) [20] and the Acute Physiology and Chronic Health Evaluation II (APACHE II) [21] scores. Sepsis and septic shock were diagnosed according to the 3rd International Consensus Definitions for Sepsis and Septic Shock (Sepsis-3) criteria [18]. Sepsis was defined as life-threatening organ dysfunction caused by a dysregulated host response to infection. Organ dysfunction can be represented by an increase in the SOFA score of $\geq 2$ points. Septic shock is a subset of sepsis that can be identified by a vasopressor requirement to maintain a mean arterial pressure $\geq 65 \mathrm{mmHg}$ and serum lactate $>2 \mathrm{mmol} / \mathrm{L}$ ( $>18 \mathrm{mg} / \mathrm{dL}$ ) in the absence of hypovolemia. We followed the criteria of the Centers for Disease Control and Prevention (CDC) [22] for the diagnosis of nosocomial infections during ICU stay (Additional file 1). We checked that no patient had any infection before the major surgical intervention and that all septic patients had a confirmed source of infection.

\section{Clinical end-points and statistical analysis}

The primary endpoint in both groups was mortality at 90 days after diagnosis of sepsis/septic shock. Secondary endpoints were length of ICU stay and time to extubation.

Sample size calculation was based on the percentage of surgical patients with a $\mathrm{PaO}_{2}$ above or below $100 \mathrm{mmHg}$ following a meaningful methodological perspective.
Assuming a 90 -day mortality of $25 \%$ and $40 \%$ respectively, a risk alpha of $5 \%$, a power of $80 \%$ in a bilateral contrast and estimating a loss rate of $30 \%$, a sample size of 216 subjects in each group was estimated. Differences between groups were assessed using $\chi^{2}$ test for categorical variables and the Mann Whitney $U$ test for continuous variables. We analyzed probability of death to day- 90 after sepsis diagnosis in both groups using Kaplan-Meier curves and tested with the log-rank test (Mantel-Haenszel). The relationship between $\mathrm{PaO}_{2}$ and mortality was plotted to examine the dose-response curve [23]. We considered 2 -sided $p$-values $<0.05$ to indicate statistical significance. The potential association between $\mathrm{PaO}_{2}$ levels and risk of 90-day mortality was further evaluated by using a multivariate logistic regression analysis. Potential confounding factors for logistic regression were identified from variables described in Table 1 . Those variables yielding a $p$-value $<0.1$ in the univariate regression analysis were included in the multivariate analysis as adjusting variables. A sub-analysis following this methodology was performed excluding patients with severe hypoxemia $\left(\mathrm{PaO}_{2}<60 \mathrm{mmHg}\right)$ at the time of inclusion into the study. We calculated the optimal operating point (OOP) of the multivariate regression model, being the value for which the point on the curve had the minimum distance to the upper left corner (where sensitivity $=1$, and specificity $=1$ ). By Pythagoras' theorem this distance is: Optimal Operating Point (OOP) $=\sqrt{ }(1-\text { sensitivity })^{2}+(1-\text { specificity })^{2}$. All data were analyzed using the IBM SPSS 22.0 software (SPSS, Chicago, IL) and R version 3.0.1 (R Foundation for Statistical Computing, Vienna, Austria).

\section{Results}

A total of 238 patients had a $\mathrm{PaO}_{2} \leq 100 \mathrm{mmHg}$ and 216 patients had $\mathrm{a}_{\mathrm{PaO}_{2}}>100 \mathrm{mmHg}$ at study inclusion. Baseline characteristics of patients are reported in Table 1. We found that patients in the group of $\mathrm{PaO}_{2} \leq 100 \mathrm{mmHg}$ had higher organ dysfunction (SOFA score 9 [3] vs. 7 [5], $p<0.001)$, and prevalence of septic shock (84.0\% [200] vs. $67.1 \%$ [145], $p<0.001$. Also, higher levels of C-reactive protein $(250.55$ [176.50] vs. $232[155.40], p=0.039)$ $(\mathrm{mg} / \mathrm{L})$, and APACHE II score (16 [7] vs. 14 [7], $p<0.001)$ were more common in the group of patients with $\mathrm{PaO}_{2} \leq 100 \mathrm{mmHg}$.

Patients with $\mathrm{PaO}_{2}>100 \mathrm{mmHg}$ had lower 90-day mortality (25.5\% [55] vs. $37.0 \%$ [88], $p=0.008)$, reduced length of ICU stay (5 [9] vs. 8 [13] days, $p<0.001$ ) and shorter duration of mechanical ventilation (1 [4] vs. 2 [8] days, $p<0.001)$. On average, patients with $\mathrm{PaO}_{2}>100 \mathrm{mmHg}$ died 7.8 days later (mean survival time 63.3 vs 71.1 days) when assessing 90-day mortality

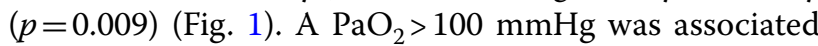


Table 1 Baseline characteristics of patients

$\mathrm{PaO}_{2} \leq 100 \mathrm{mmHg}(1)(n=238)$

$\mathrm{PaO}_{2}>100 \mathrm{mmHg}(2) \quad p$ value (1 vs. 2 ) $(n=216)$

Characteristics

Age [years, median [IQR]]

$3[14]$

$72[16]$

0.69

Male $[\%,(n)]$

$65.5(156)$

$54.6(118)$

0.028

Comorbidities [\% (n)]

Chronic cardiovascular disease

34.9 (83)

$27.8(60)$

0.09

Chronic respiratory disease

$22.3(53)$

$12.5(27)$

0.005

High blood pressure

$59.7(142)$

$54.6(118)$

0.22

Chronic renal failure

$8.4(20)$

$9.7(21)$

0.66

Chronic hepatic failure

$3.3(8)$

$4.2(9)$

0.67

Diabetes mellitus

$22.7(54)$

Cancer

$27.3(65)$

$22.2(48)$

0.86

Immunosuppression

$4.6(11)$

39.4 (85)

0.008

Obesity

3.7 (8)

0.61

18.5 (44)

$11.1(24)$

0.024

Surgery type, [\% (n)]

Abdominal

$60.9(145)$

$76.4(165)$

0.009

Cardio-thoracic

$2.9(7)$

$3.2(7)$

0.98

Vascular

$6.3(15)$

$3.2(7)$

0.07

$2.1(5)$

$2.3(5)$

0.99

Other

4.6 (11)

$2.3(5)$

0.12

Source of infection, [\% (n)]

Respiratory tract

$32.9(73)$

$16.3(33)$

$<0.001$

Abdomen

$50.0(111)$

Urinary tract

$3.4(8)$

Surgical site

$0.8(2)$

Bacteremia

$3.8(9)$

Other

$11.3(27)$

$61.9(125)$

0.014

$4.6(10)$

0.50

$1.4(3)$

0.58

$3.2(7)$

0.74

$11.6(25)$

0.96

Microbiology, [\% (n)]

Gram +

$29.4(70)$

$29.2(63)$

0.95

Gram -

$38.2(91)$

$31.0(67)$

0.11

Fungi

16.4 (39)

$10.6(23)$

0.08

Measurements at diagnosis [median [IQR]]

$\mathrm{PaO}_{2}(\mathrm{mmHg})$

74.15 [25]

134 [45]

$<0.001$

$\mathrm{FiO}_{2}$

$0.50[0.05]$

$0.50[0]$

0.47

157.64 [73.45]

278 [108.50]

$<0.001$

$\mathrm{PaO}_{2}$ at $48 \mathrm{~h}(\mathrm{mmHg})$

$71.50[25]$

131 [45]

$<0.001$

Total bilirubin $(\mathrm{mg} / \mathrm{dl})$

$0.89[1.06]$

0.75 [0.82]

0.12

168 [76.15]

171 [75.25]

0.82

Creatinine $(\mathrm{mg} / \mathrm{dl})$

$1.90[2.51]$

$1.51[1.73]$

0.001

$\mathrm{Na}(\mathrm{mmol} / \mathrm{L})$

137 [6]

$136[5]$

0.024

$\mathrm{K}(\mathrm{mmol} / \mathrm{L})$

4 [1.1]

Platelet count (cells/mm³)

$173,000[155500]$

Lactate (mmol/L)

$2.66[2.17]$

Procalcitonin ( $\mathrm{ng} / \mathrm{ml})$

$5.50[16.28]$

4 [1]

0.54

197,000 [184000] $\quad 0.014$

$2.20[2.20] \quad 0.08$

$5.05[23.41] \quad 0.61$

C-Reactive Protein (mg/L)

250.55 [176.50]

232 [155.40]

0.039

13,660 [12295]

12,955 [10521]

0.06

961.65 [988.14]

767.70 [901.52]

0.003

Lymphocytes (cells $/ \mathrm{mm}^{3}$ )

$11,727.31$ [11263.94]

$11,308.80$ [9629.29]

0.16

66.4 (158)

80.1 (173)

0.001

Urgent surgery

9 [3]

7 [5]

$<0.001$ 
Table 1 (continued)

\begin{tabular}{|c|c|c|c|}
\hline & $\mathrm{PaO}_{2} \leq 100 \mathrm{mmHg}(1)(n=238)$ & $\begin{array}{l}\mathrm{PaO}_{2}>100 \mathrm{mmHg}(2) \\
(n=216)\end{array}$ & $p$ value (1 vs. 2 ) \\
\hline APACHE II score & $16[7]$ & $14[7]$ & $<0.001$ \\
\hline \multicolumn{4}{|l|}{ Time course and outcome } \\
\hline Length of hospital stay [days, median (IQR)] & $25[24]$ & $23.50[27]$ & 0.97 \\
\hline Length of ICU stay [days, median (IQR)] & $8[13]$ & $5[9]$ & $<0.001$ \\
\hline Length of mechanical ventilation [days, median (IQR)] & $2[8]$ & $1[4]$ & $<0.001$ \\
\hline Sepsis $[\%(n)]$ & $16.0(38)$ & $32.9(71)$ & $<0.001$ \\
\hline Septic shock [\% (n)] & $84.0(200)$ & $67.1(145)$ & $<0.001$ \\
\hline Mortality at 90 days [\% (n)] & $37.0(88)$ & $25.5(55)$ & 0.008 \\
\hline
\end{tabular}

Continuous variables are represented as median and interquartile range (IQR); categorical variables are represented as percentages (\%) and number (n). ICU: intensive care unit; SOFA: Sequential Organ Failure Assessment Score

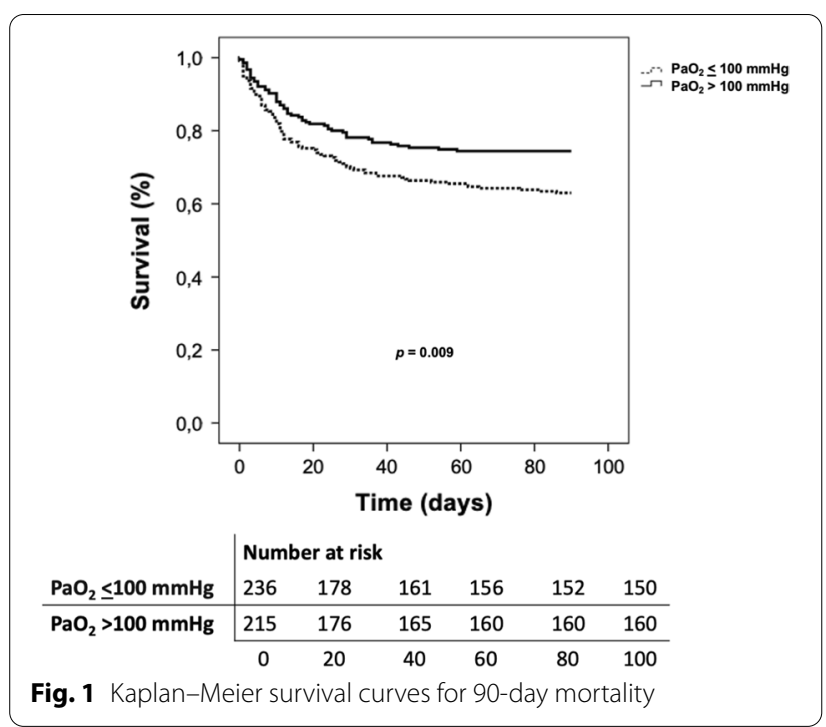

with higher probability of 90-day survival (OR 0.61, 95\% CI 0.39-0.95, $p=0.029$ ). This association was independent of age, presence of chronic renal failure, procalcitonin levels, or APACHE II score above 19 in the multivariate analysis (Table 2). The lower the value of $\mathrm{PaO}_{2}$, the greater the risk of death at 90 days (Fig. 2).

On average, patients with $\mathrm{PaO}_{2}>100 \mathrm{mmHg}$ had lower ICU stay (mean values 7.7 vs 10.6 days) when assessing 28-day ICU stay $(p=0.001)$ (Additional file 1: Fig. S1). Patients with $\mathrm{PaO}_{2}>100 \mathrm{mmHg}$ were extubated 1.7 days earlier (mean values 4.0 vs 5.7 ) when assessing a 28 -day intubation period $(p=0.022)$ (Additional file 1: Fig. S1). The optimal operating point (OOP) of the multivariate analysis has a sensitivity of $63.4 \%$ and a specificity of $68.9 \%$ for predicting mortality. Patients with levels over this OOP died 22 days before on average (mean survival time 75.9 vs 54.2 days) (Additional file 1: Fig. S2). These results were confirmed when a further sub-analysis was performed excluding more severely hypoxemic patients $\left(\mathrm{PaO}_{2}<60 \mathrm{mmHg}\right)$ at the time of study inclusion (Additional file 1: Table S1, Figs. S3 and S4).

\section{Discussion}

In the present study in 454 patients with sepsis/septic shock, a $\mathrm{PaO}_{2}>100 \mathrm{mmHg}$ during the first $48 \mathrm{~h}$ after major surgery was associated with a lower risk of 90-day mortality, lower length of ICU stay and reduced time to extubation. Similar results were obtained when patients with $\mathrm{PaO}_{2}<60 \mathrm{mmHg}$ were excluded. Our findings could

Table 2 Univariate and multivariate analysis for evaluating the risk of mortality at 90 days

\begin{tabular}{|c|c|c|c|c|c|c|c|c|}
\hline & \multicolumn{4}{|c|}{ Univariate analysis } & \multicolumn{4}{|c|}{ Multivariate analysis } \\
\hline & OR & [Cl 95\%] & & $p$ & OR & {$[\mathrm{Cl} 9$} & & $p$ \\
\hline Age & 1.04 & 1.02 & 1.06 & $<0.001$ & 1.03 & 1.01 & 1.05 & 0.008 \\
\hline Chronic renal failure & 2.84 & 1.48 & 5.44 & 0.002 & 2.93 & 1.44 & 5.96 & 0.003 \\
\hline $\mathrm{PCT}(\mathrm{ng} / \mathrm{mL}) \mathrm{Ln}$ & 1.22 & 1.07 & 1.37 & 0.002 & 1.16 & 1.02 & 1.33 & 0.029 \\
\hline APACHE $\|>19$ & 3.74 & 2.26 & 6.21 & $<0.001$ & 2.96 & 1.72 & 5.11 & $<0.001$ \\
\hline $\mathrm{PaO}_{2}>100 \mathrm{mmHg}$ & 0.58 & 0.39 & 0.87 & 0.009 & 0.61 & 0.39 & 0.95 & 0.029 \\
\hline
\end{tabular}

$\mathrm{Cl}$, Confidence interval; OR, odds ratio; PCT, procalcitonin; APACHE II, acute physiology and chronic health evaluation II 


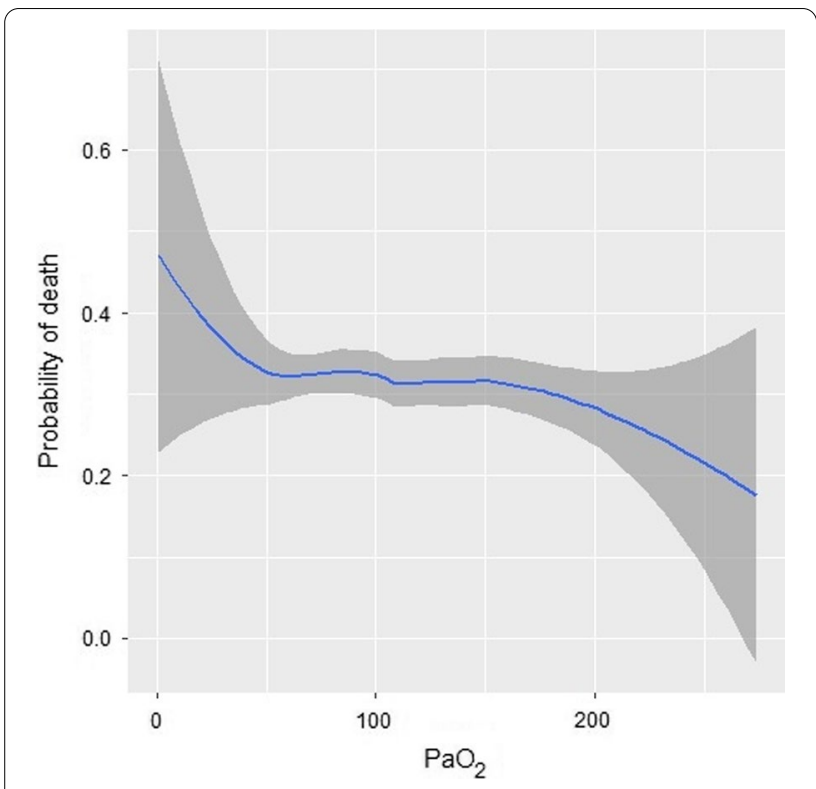

Fig. 2 Adjusted probability of mortality by arterial oxygen levels. Grey zones represent 95\% confidence intervals

have an important clinical relevance for reducing overall mortality in postoperative patients developing sepsis/ septic shock.

Hyperoxemia and hypoxemia have been associated with increased mortality in mechanically ventilated patients [24-27]. A recent meta-analysis in critically ill patients suggested a reduction in overall mortality with the use of conservative [median baseline $\mathrm{SpO}_{2}$ 96.7\% (range 93.4-98.0\%; IQR 95.0-97.0)] compared to liberal oxygen therapy [median baseline $\mathrm{SpO}_{2}$ 96.4\% (range 94.0-99.0\%; IQR 95.8-97.8)] [28]. However, in different subpopulations of critically ill patients the evidence is less certain, and the optimal oxygen strategy is still unknown. This is also due to the fact that oxygen thresholds are different and arbitrary among studies [29]. In patients with cardiac ischaemia or stroke, recent guidelines stated a strong recommendation against the use of oxygen therapy in non-hypoxaemic patients [peripheral oxygen saturation $\left(\mathrm{SpO}_{2}\right) \geq 93 \%$ ] [30]. An association between severe hyperoxemia $\left(\mathrm{PaO}_{2}>300 \mathrm{mmHg}\right)$ [31] and increased mortality has been reported in patients where lung function was relatively preserved compared to either hypoxemia $\left(\mathrm{PaO}_{2}<60 \mathrm{mmHg}\right)$ or normoxemia $\left(\mathrm{PaO}_{2} 60-300 \mathrm{mmHg}\right)$, such as after cardiac arrest [31-34], stroke [35], and traumatic brain injury [3638]. Helmerhorst et al. [39] found that hyperoxia [the most commonly used threshold was $300 \mathrm{mmHg}$ (range, 85-487 $\mathrm{mm} \mathrm{Hg}$ )] was associated with poor hospital outcome in a meta-analysis, including various subsets of critically ill patients from heterogeneous studies. On the other hand, Vaahersalo et al. [40] described an improved long-term outcome with moderate hyperoxia $\left(\mathrm{PaO}_{2} 128-237 \mathrm{mmHg}\right)$ in cardiac arrest, while other authors did not show any difference in several biomarkers of brain injury comparing a $\mathrm{PaO}_{2}$ of $75-113 \mathrm{mmHg}$ to $150-188 \mathrm{mmHg}[41,42]$.

The association between hyperoxemia and outcome in sepsis/septic shock also remains to be unclear [43-46]. A post-hoc analysis of the HYPERS2S study revealed that hyperoxia $\left(\mathrm{FiO}_{2} 1.0\right)$ in comparison to normoxia $\left(\mathrm{FiO}_{2}\right.$ set to target an arterial oxygen saturation of $88-95 \%$ ) may be associated with increased 90-day mortality [16]. However, a recent study evaluating the effects of hyperoxemia $\left(\mathrm{PaO}_{2}>120 \mathrm{mmHg}\right)$ vs. normoxemia $\left(\mathrm{PaO}_{2}\right.$ between $70-120 \mathrm{mmHg}$ ) on mortality in mechanically ventilated ICU patients with septic shock found no impact on mortality in this patient population [15]. In the ICU-ROX trial [45], conservative oxygen therapy [oxygen saturation measured by pulse oximetry $\left(\mathrm{SpO}_{2}\right)$ between 90 and $97 \%$ ] did not show differences when compared to liberal oxygen therapy (there was no protocol-defined upper limit of $\mathrm{SpO}_{2}$ ) in terms of ventilator-free days and mortality at 90 and 180 days. These results are in contrast with those from a previous trial in which conservative oxygen therapy $\left(\mathrm{PaO}_{2} 70-100 \mathrm{mmHg}\right)$ was associated with a lower rate of deaths in comparison with conventional control group $\left(\mathrm{PaO}_{2}\right.$ up to $\left.150 \mathrm{mmHg}\right)$ [44]. On the other hand, a post-hoc analysis of the ICU-ROX study revealed that higher $\mathrm{PaO}_{2}$ treatment in sepsis/septic shock patients was associated with a reduction in 90-day mortality, in line with our findings, while conservative oxygen therapy may be harmful [17]. In addition, the LOCO-2 study conducted in ARDS patients did not report differences in mortality at 28 days when using a conservative oxygenation therapy $\left(\mathrm{PaO}_{2} 55-70 \mathrm{mmHg} ; \mathrm{SpO}_{2}\right.$ of 88 to $92 \%)$ vs. liberal oxygen therapy $\left(\mathrm{PaO}_{2} 90-105 \mathrm{mmHg}\right.$; $\mathrm{SpO}_{2} \geq 96 \%$ ) [47]. Gelissen et al. [48] reported that among critically ill patients with 2 or more SIRS criteria, treatment with a low-normal $\mathrm{PaO}_{2}$ target $\left(\mathrm{PaO}_{2}\right.$ range of 60-90 mmHg) compared with a high-normal $\mathrm{PaO}_{2}$ target $\left(\mathrm{PaO}_{2}\right.$ range of $\left.105-135 \mathrm{mmHg}\right)$ did not result in a reduction in organ dysfunction. Zhang et al. [49] reported that the effect of $\mathrm{PaO}_{2}$ on mortality risk is a quadratic function in sepsis, in which both low and high $\mathrm{PaO}_{2}$ were associated with a high mortality risk. Specifically, an increment in $\mathrm{PaO}_{2}$ up to $300 \mathrm{mmHg}$ was associated with reduced risk of death, in agreement with our findings.

We also found a lower length of ICU stay and time to extubation in sepsis/septic shock patients with $\mathrm{PaO}_{2}$ above $100 \mathrm{mmHg}$. In contrast with our findings, Yamamoto et al. [50] found an association between hyperoxemia and longer ICU stay and time to extubation. 
However, they included a subset of trauma patients where hyperoxemia was defined as $\mathrm{PaO}_{2} \geq 300 \mathrm{mmHg}$. Six et al. [51] found no association between hyperoxemia $\left(\mathrm{SpO}_{2} \geq 98 \%\right)$ and ICU stay or time to extubation in critically ill patients with ventilator-associated pneumonia, but the definition used for hyperoxemia was based on an arbitrary threshold and the sample size was underpowered. In line with our findings, several studies have reported the potential role of supplemental perioperative oxygen to reduce the rate of surgical-wound infections in postsurgical patients [11-13].

The results of most studies are contradictory as they include heterogeneous patients using different oxygen thresholds. Most of these studies included patients with sepsis criteria but failed to isolate any germ in the cultures. Also, in those studies, the authors did not report whether the antibiotic was administered according to the antibiogram, nor reported the duration of antimicrobial stewardship. An important part of antimicrobial stewardship is to restrict antimicrobial therapy to the shortest course associated with best outcomes [52-56]. The optimal duration of antimicrobial therapy for a given sepsis/ septic shock patient depends on several factors $[57,58]$. Sepsis guidelines recommend a duration of antibiotic treatment to 3 days. It is understood that for an effective combination of oxygen, neutrophil function, and antibiotic it should last at least $48-72$ h. Neutrophil dysfunction and low levels of partial pressure of tissue oxygen $\left(\mathrm{PsqO}_{2}\right)$ could explain the failure of appropriate antibiotic treatment. Neutrophils are the final effectors cells of innate immunity with a primary role in the clearance of extracellular pathogens mediated by oxidative killing [ 9 , 10]. Killing by oxidation is the most important defense mechanism against surgical pathogens, and depends on $\mathrm{PsqO}_{2}$ in contaminated tissue [11]. High $\mathrm{PaO}_{2}$ acts at systemic levels to increase partial pressure of tissue oxygen $\left(\mathrm{PsqO}_{2}\right)$ [59]. The risk of infection is, therefore, inversely related to $\mathrm{PsqO}_{2}$ [59]. Furthermore, the presence of high $\mathrm{PaO}_{2}$ enhances neutrophil superoxide production, thus potentially improving pathogen killing by the innate immune system (Additional file 1: Fig. S5) [17]. During sepsis, oxygen delivery to the tissues may be impaired in some patients, making liberal provision of oxygen of great value. Thus, the use of high $\mathrm{PaO}_{2}$ might directly reduce the consequences of infections via enhanced oxidative killing of bacteria and indirectly in patients presenting wounds by re-epithelialization, blood vessel angiogenesis, and tissue collagen synthesis, which improves wound healing [17].

We acknowledge some limitations of our study. First, this is a secondary analysis of a prospective study to identify sepsis/septic shock patients and not for testing whether a threshold for $\mathrm{PaO}_{2}$ had any impact on hospital mortality in a randomized controlled study design. As a result, pathogen clearance and infection resolution were not evaluated because our study database was not designed to assess the effects of oxygen. Second, our study only monitored oxygen values for $48 \mathrm{~h}$. Third, our study was conducted in a single center and should be tested in a multicenter fashion design to validate the potential role of $\mathrm{PaO}_{2}$ in predicting mortality in surgical patients with infection.

\section{Conclusions}

In summary, oxygenation with a $\mathrm{PaO}_{2}$ above $100 \mathrm{mmHg}$ was independently associated with lower 90-day mortality, shorter ICU stay and intubation time in critically ill postsurgical sepsis/septic shock patients. Our findings open a new venue for designing clinical trials to evaluate the boundaries of $\mathrm{PaO}_{2}$ in postsurgical patients with severe infections.

\section{Supplementary Information}

The online version contains supplementary material available at https://doi. org/10.1186/s13054-021-03875-0.

\section{Additional file 1: File 1. Supplementary methods regarding treatment, diagnosis and definitions of patients recruited for the study. Figure S1. (A) Kaplan-Meier curve for 28-day intubation. (B) Kaplan-Meier curve for 28-day ICU stay. Figure S2. Kaplan-Meier survival curves for 90-day mortality of the multivariate regression model. Table S1. Univariate and multivariate analysis for evaluating the risk of mortality at 90 days excluding patients with severe hypoxemia $\left(\mathrm{PaO}_{2}<60 \mathrm{mmHg}\right)$ at the time of inclusion into the study. Figure S3. Kaplan-Meier survival curves for 90-day mortality excluding patients with severe hypoxemia $\left(\mathrm{PaO}_{2}<60 \mathrm{mmHg}\right)$ at the time of inclusion into the study. Figure S4. (A) Kaplan-Meier curve for 28-day intubation excluding patients with severe hypoxemia $\left(\mathrm{PaO}_{2}<60 \mathrm{mmHg}\right.$ ) at the time of inclusion into the study. (B) Kaplan-Meier curve for 28-day ICU stay excluding patients with severe hypoxemia $\left(\mathrm{PaO}_{2}<60 \mathrm{mmHg}\right)$ at the time of inclusion into the study. Figure S5. Neutrophils' bactericidal activity mediated by oxidative killing.}

\section{Acknowledgements}

This study has been possible thank to the collaboration of all patients and their relatives, and the medical and nursery staff of the participating clinical service for their continuous support. The authors thank data managers who have taken part in the project.

\section{Authors' contributions}

$M M F, P P, J V$ and $E T$ contributed to the conception and design of the work. MHR, IGJ, MLL, EGP, RPA, FJA, PJM, JBH, EGA, FHG, GG, EGS, ATV and RA assisted with the acquisition of data and study management. MMF and MHR contributed to analysis and interpretation of data. MMF, MHR, PP, JV and ET drafted the manuscript for intellectual content. ET and JV are responsible for the funding of the study. MMF, MHR, IGJ, MLL, EGP, RPA, FJA, PJM, JBH, EGA, FHG, $G G, E G S, A T V, R A, P P, J V$ and $E T$ had full access to all the data in the study and take responsibility for the integrity of the data and the accuracy of the data analysis. All authors read and approved the final manuscript.

\section{Funding}

Supported, in part, by the Instituto de Salud Carlos III (PI18/01238), Junta de Castilla y León (VA321P18, GRS 1922/A/19, GRS 2057/A/19) and Fundación Ramón Areces (CIVP19A5953). J. Villar has received Grants from Instituto de Salud Carlos III (CB06/06/1088, PI16/00049, PI 19/00141). 


\section{Availability of data and materials}

The datasets used and/or analysed during the current study are available from the corresponding author on reasonable request.

\section{Declarations}

\section{Ethics approval and consent to participate}

The study protocol was approved by the Ethics Committee for Clinical Research, Hospital Clínico Universitario in Valladolid, Spain (approval No. PI 20-2070). This study followed current Spanish legislation for biomedical research, fulfilling the standards indicated by the Declaration of Helsinki. Written informed consent was obtained from patients, patients' relatives or their legal representative before enrolment.

\section{Consent for publication}

Not applicable.

\section{Competing interests}

The authors declare that they have no competing interests.

\section{Author details}

${ }^{1}$ Department of Medicine, Toxicology and Dermatology, University of Valladolid, Valladolid, Spain. ${ }^{2}$ BioCritic, Group for Biomedical Research in Critical Care Medicine, Valladolid, Spain. ${ }^{3}$ Centro de Investigación Biomédica en Red de Enfermedades Infecciosas (CIBERINFEC), Instituto de Salud Carlos III, Madrid, Spain. ${ }^{4}$ Department of Anaesthesiology and Critical Care, Hospital Clínico Universitario de Salamanca, Salamanca, Spain. ${ }^{5}$ Department of Anaesthesiology and Critical Care, Hospital Clínico Universitario de Valladolid, Valladolid, Spain. ${ }^{6}$ Department of Pharmacology, University of Valladolid, Valladolid, Spain. ${ }^{7}$ Department of Surgery, University of Valladolid, Valladolid, Spain. ${ }^{8}$ Transplantation Center, Lausanne University Hospital and University of Lausanne, Lausanne, Switzerland. ${ }^{9}$ Department of Hematology, Hospital Clínico Universitario de Valladolid, Valladolid, Spain. ${ }^{10}$ Department of Gastroenterology, Hospital Clínico Universitario de Valladolid, Valladolid, Spain. ${ }^{11}$ Department of Surgical Sciences and Integrated Diagnostics, University of Genoa, Genoa, Italy. ${ }^{12}$ IRCCS for Oncology and Neurosciences, San Martino Policlinico Hospital, Genoa, Italy. ${ }^{13}$ CIBER de Enfermedades Respiratorias, Instituto de Salud Carlos III, Madrid, Spain. ${ }^{14}$ Research Unit, Hospital Universitario Dr. Negrín, Barranco de la Ballena s/n, 4th Floor-South Wing, 35019 Las Palmas de Gran Canaria, Spain. ${ }^{15} \mathrm{Li}$ Ka Shing Knowledge Institute at St. Michael's Hospital, Toronto, ON, Canada.

Received: 15 September 2021 Accepted: 20 December 2021 Published online: 10 January 2022

\section{References}

1. Angus DC, Linde-Zwirble WT, Lidicker J, Clermont G, Carcillo J, Pinsky MR. Epidemiology of severe sepsis in the United States: analysis of incidence, outcome, and associated costs of care. Crit Care Med. 2001;29:1303-10.

2. Moore LJ, Moore FA, Todd SR, Jones SL, Turner KL, Bass BL. Sepsis in general surgery: the 2005-2007 national surgical quality improvement program perspective. Arch Surg Chic III. 1960;2010(145):695-700.

3. Liu V, Escobar GJ, Greene JD, Soule J, Whippy A, Angus DC, et al. Hospital deaths in patients with sepsis from 2 independent cohorts. JAMA Am Med Assoc. 2014;312:90-2.

4. Rhee C, Dantes R, Epstein L, Murphy DJ, Seymour CW, Iwashyna TJ, et al. Incidence and trends of sepsis in US hospitals using clinical vs claims data, 2009-2014. JAMA Am Med Assoc. 2017:318:1241-9.

5. Arefian H, Heublein S, Scherag A, Brunkhorst FM, Younis MZ, Moerer O, et al. Hospital-related cost of sepsis: a systematic review. J Infect. 2017:74:107-17.

6. Álvaro-Meca A, Jiménez-Sousa MA, Micheloud D, Sánchez-Lopez A, Heredia-Rodríguez M, Tamayo E, et al. Epidemiological trends of sepsis in the twenty-first century (2000-2013): an analysis of incidence, mortality, and associated costs in Spain. Popul Health Metr. 2018;16:4.

7. Evans L, Rhodes A, Alhazzani W, Antonelli M, Coopersmith CM, French C, et al. Surviving sepsis campaign: international guidelines for management of sepsis and septic shock 2021. Intensive Care Med. 2021:47:1181-247.
8. Vincent J-L, De Backer D. Circulatory shock. N Engl J Med. 2013;369:1726-34.

9. Teng T-S, Ji A-L, Ji X-Y, Li Y-Z. Neutrophils and immunity: from bactericidal action to being conquered. J Immunol Res. 2017;2017:9671604.

10. Babior BM. Oxygen-dependent microbial killing by phagocytes (first of two parts). N Engl J Med. 1978;298:659-68.

11. Greif R, Akça O, Horn EP, Kurz A, Sessler DI. Outcomes research group. Supplemental perioperative oxygen to reduce the incidence of surgicalwound infection. N Engl J Med. 2000;342:161-7.

12. Brasel K, McRitchie D, Dellinger P, EBRS Group. Canadian Association of General Surgeons and American College of Surgeons Evidence Based Reviews in Surgery. 21: the risk of surgical site infection is reduced with perioperative oxygen. Can J Surg J Can Chir. 2007:50:214-6.

13. Belda FJ, Aguilera L, de la Asunción JG, Alberti J, Vicente R, Ferrándiz L, et al. Supplemental perioperative oxygen and the risk of surgical wound infection: a randomized controlled trial. JAMA. 2005;294:2035-42.

14. Stolmeijer R, ter Maaten JC, Zijlstra JG, Ligtenberg JJM. Oxygen therapy for sepsis patients in the emergency department: a little less? Eur J Emerg Med. 2014;21:233-5.

15. Popoff B, Besnier E, Dureuil B, Veber B, Clavier T. Effect of early hyperoxemia on mortality in mechanically ventilated septic shock patients according to Sepsis-3 criteria: analysis of the MIMIC-III database. Eur J Emerg Med. 2021;28:469-75.

16. Asfar P, Schortgen F, Boisramé-Helms J, Charpentier J, Guérot E, Megarbane $\mathrm{B}$, et al. Hyperoxia and hypertonic saline in patients with septic shock (HYPERS2S): a two-by-two factorial, multicentre, randomised, clinical trial. Lancet Respir Med. 2017:5:180-90.

17. Young P, Mackle D, Bellomo R, Bailey M, Beasley R, Deane A, et al. Conservative oxygen therapy for mechanically ventilated adults with sepsis: a post hoc analysis of data from the intensive care unit randomized trial comparing two approaches to oxygen therapy (ICU-ROX). Intensive Care Med. 2020:46:17-26.

18. Singer M, Deutschman CS, Seymour CW, Shankar-Hari M, Annane D, Bauer $M$, et al. The third international consensus definitions for sepsis and septic shock (sepsis-3). JAMA. 2016:315:801-10.

19. Madotto F, Rezoagli E, Pham T, Schmidt M, McNicholas B, Protti A, et al. Hyperoxemia and excess oxygen use in early acute respiratory distress syndrome: insights from the LUNG SAFE study. Crit Care. 2020;24:125.

20. Vincent JL, Moreno R, Takala J, Willatts S, De Mendonça A, Bruining $\mathrm{H}$, et al. The SOFA (Sepsis-related Organ Failure Assessment) score to describe organ dysfunction/failure. On behalf of the working group on sepsis-related problems of the European society of intensive care medicine. Intensive Care Med. 1996;22:707-10.

21. Knaus WA, Draper EA, Wagner DP, Zimmerman JE. APACHE II: a severity of disease classification system. Crit Care Med. 1985;13:818-29.

22. CDC/NHSN surveillance definitions for specific types of infections. 2021:30.

23. Helmerhorst HJF, Roos-Blom M-J, van Westerloo DJ, Abu-Hanna A, de Keizer NF, de Jonge E. Associations of arterial carbon dioxide and arterial oxygen concentrations with hospital mortality after resuscitation from cardiac arrest. Crit Care Lond Engl. 2015;19:348.

24. Flower L, Martin D. Management of hypoxaemia in the critically ill patient. Br J Hosp Med Lond Engl. 2005;2020(81):1-10.

25. SRLF Trial Group. Hypoxemia in the ICU: prevalence, treatment, and outcome. Ann Intensive Care. 2018;8:82.

26. Aggarwal NR, Brower RG, Hager DN, Thompson BT, Netzer G, Shanholtz $\mathrm{C}$, et al. Oxygen exposure resulting in arterial oxygen tensions above the protocol goal was associated with worse clinical outcomes in acute respiratory distress syndrome. Crit Care Med. 2018;46:517-24.

27. de Jonge E, Peelen L, Keijzers PJ, Joore H, de Lange D, van der Voort PHJ, et al. Association between administered oxygen, arterial partial oxygen pressure and mortality in mechanically ventilated intensive care unit patients. Crit Care Lond Engl. 2008;12:R156.

28. Chu DK, Kim LH-Y, Young PJ, Zamiri N, Almenawer SA, Jaeschke R, et al. Mortality and morbidity in acutely ill adults treated with liberal versus conservative oxygen therapy (IOTA): a systematic review and meta-analysis. Lancet Lond Engl. 2018;391:1693-705.

29. Girardis M, Alhazzani W, Rasmussen BS. What's new in oxygen therapy? Intensive Care Med. 2019:45:1009-11. 
30. Siemieniuk RAC, Chu DK, Kim LH-Y, Güell-Rous M-R, Alhazzani W, Soccal PM, et al. Oxygen therapy for acutely ill medical patients: a clinical practice guideline. BMJ. 2018;363:K4169.

31. Kilgannon JH, Jones AE, Shapiro NI, Angelos MG, Milcarek B, Hunter K, et al. Association between arterial hyperoxia following resuscitation from cardiac arrest and in-hospital mortality. JAMA. 2010;303:2165-71.

32. Elmer J, Scutella M, Pullalarevu R, Wang B, Vaghasia N, Trzeciak S, et al. The association between hyperoxia and patient outcomes after cardiac arrest: analysis of a high-resolution database. Intensive Care Med. 2015:41:49-57.

33. Janz DR, Hollenbeck RD, Pollock JS, McPherson JA, Rice TW. Hyperoxia is associated with increased mortality in patients treated with mild therapeutic hypothermia after sudden cardiac arrest. Crit Care Med. 2012:40:3135-9.

34. Ni Y-N, Wang Y-M, Liang B-M, Liang Z-A. The effect of hyperoxia on mortality in critically ill patients: a systematic review and meta analysis. BMC Pulm Med. 2019;19:53.

35. Rincon F, Kang J, Maltenfort M, Vibbert M, Urtecho J, Athar MK, et al. Association between hyperoxia and mortality after stroke: a multicenter cohort study. Crit Care Med. 2014;42:387-96.

36. Davis DP, Meade W, Sise MJ, Kennedy F, Simon F, Tominaga G, et al. Both hypoxemia and extreme hyperoxemia may be detrimental in patients with severe traumatic brain injury. J Neurotrauma. 2009;26:2217-23.

37. Rincon F, Kang J, Vibbert M, Urtecho J, Athar MK, Jallo J. Significance of arterial hyperoxia and relationship with case fatality in traumatic brain injury: a multicentre cohort study. J Neurol Neurosurg Psychiatry. 2014:85:799-805.

38. Asher SR, Curry P, Sharma D, Wang J, O'Keefe GE, Daniel-Johnson J, et al. Survival advantage and $\mathrm{PaO}_{2}$ threshold in severe traumatic brain injury. J Neurosurg Anesthesiol. 2013;25:168-73.

39. Helmerhorst HJF, Roos-Blom M-J, van Westerloo DJ, de Jonge E. Association between arterial hyperoxia and outcome in subsets of critical illness: a systematic review, meta-analysis, and meta-regression of cohort studies. Crit Care Med. 2015;43:1508-19.

40. Vaahersalo J, Bendel S, Reinikainen M, Kurola J, Tiainen M, Raj R, et al. Arterial blood gas tensions after resuscitation from out-of-hospital cardiac arrest: associations with long-term neurologic outcome. Crit Care Med. 2014:42:1463-70.

41. Jakkula P, Reinikainen $M$, Hästbacka J, Loisa P, Tiainen M, Pettilä V, et al. Targeting two different levels of both arterial carbon dioxide and arterial oxygen after cardiac arrest and resuscitation: a randomised pilot trial. Intensive Care Med. 2018:44:2112-21.

42. Wihersaari L, Ashton NJ, Reinikainen M, Jakkula P, Pettilä V, Hästbacka J, et al. Neurofilament light as an outcome predictor after cardiac arrest: a post hoc analysis of the COMACARE trial. Intensive Care Med. 2021:47:39-48.

43. Martin J, Mazer-Amirshahi M, Pourmand A. The impact of hyperoxia in the critically ill patient: a review of the literature. Respir Care. 2020;65:1202-10

44. Girardis M, Busani S, Damiani E, Donati A, Rinaldi L, Marudi A, et al. Effect of conservative vs conventional oxygen therapy on mortality among patients in an intensive care unit: the oxygen-ICU randomized clinical trial. JAMA. 2016;316:1583-9.

45. ICU-ROX Investigators and the Australian and New Zealand Intensive Care Society Clinical Trials Group, Mackle D, Bellomo R, Bailey M, Beasley R, Deane A, et al. Conservative Oxygen Therapy during Mechanical Ventilation in the ICU. N Engl J Med. 2020;382:989-98.

46. Panwar R, Hardie M, Bellomo R, Barrot L, Eastwood GM, Young PJ, et al. Conservative versus liberal oxygenation targets for mechanically ventilated patients. A pilot multicenter randomized controlled trial. Am J Respir Crit Care Med. 2016;193:43-51.

47. Barrot L, Asfar P, Mauny F, Winiszewski H, Montini F, Badie J, et al. Liberal or conservative oxygen therapy for acute respiratory distress syndrome. N Engl J Med. 2020;382:999-1008.

48. Gelissen H, de Grooth H-J, Smulders Y, Wils E-J, de Ruijter W, Vink R, et al. Effect of low-normal vs high-normal oxygenation targets on organ dysfunction in critically ill patients: a randomized clinical trial. JAMA. 2021:326:940-8.

49. Zhang Z, Ji X. Quadratic function between arterial partial oxygen pressure and mortality risk in sepsis patients: an interaction with simplified acute physiology score. Sci Rep. 2016;6:35133.
50. Yamamoto R, Fujishima S, Sasaki J, Gando S, Saitoh D, Shiraishi A, et al. Hyperoxemia during resuscitation of trauma patients and increased intensive care unit length of stay: inverse probability of treatment weighting analysis. World J Emerg Surg WJES. 2021;16:19.

51. Six S, Rouzé A, Pouly O, Poissy J, Wallet F, Preau S, et al. Impact of hyperoxemia on mortality in critically ill patients with ventilator-associated pneumonia. Ann Transl Med. 2018;6:417.

52. Wald-Dickler N, Spellberg B. Short-course antibiotic therapy-replacing constantine units with "shorter is better." Clin Infect Dis. 2019;69:1476-9.

53. Spellberg B. The new antibiotic mantra-"shorter is better". JAMA Intern Med. 2016;176:1254-5.

54. Fernandez-Lazaro Cl, Brown KA, Langford BJ, Daneman N, Garber G, Schwartz KL. Late-career physicians prescribe longer courses of antibiotics. Clin Infect Dis. 2019:69:1467-75.

55. Royer S, DeMerle KM, Dickson RP, Prescott HC. Shorter versus longer courses of antibiotics for infection in hospitalized patients: a systematic review and meta-analysis. J Hosp Med. 2018;13:336-42.

56. Hanretty AM, Gallagher JC. Shortened courses of antibiotics for bacterial infections: a systematic review of randomized controlled trials. Pharmacotherapy. 2018;38:674-87.

57. Prescott HC, Iwashyna TJ. Improving sepsis treatment by embracing diagnostic uncertainty. Ann Am Thorac Soc. 2019;16:426-9.

58. Klompas M, Calandra T, Singer M. Antibiotics for sepsis-finding the equilibrium. JAMA. 2018:320:1433-4.

59. Bakri MH, Nagem H, Sessler DI, Mahboobi R, Dalton J, Akça O, et al. Transdermal oxygen does not improve sternal wound oxygenation in patients recovering from cardiac surgery. Anesth Analg. 2008;106:1619-26.

\section{Publisher's Note}

Springer Nature remains neutral with regard to jurisdictional claims in published maps and institutional affiliations.
Ready to submit your research? Choose BMC and benefit from:

- fast, convenient online submission

- thorough peer review by experienced researchers in your field

- rapid publication on acceptance

- support for research data, including large and complex data types

- gold Open Access which fosters wider collaboration and increased citations

- maximum visibility for your research: over $100 \mathrm{M}$ website views per year

At BMC, research is always in progress.

Learn more biomedcentral.com/submissions 